\title{
Seroprevalence of Rift Valley fever and lumpy skin disease in African buffalo (Syncerus caffer) in the Kruger National Park and Hluhluwe-iMfolozi Park, South Africa
}

\author{
Authors: \\ Shamsudeen Fagbo ${ }^{1,2}$ \\ Jacobus A.W. Coetzer ${ }^{2}$ \\ Estelle H. Venter ${ }^{2}$ \\ Affiliations: \\ ${ }^{1}$ Zoonotic Diseases Unit, \\ Ministry of Health, Saudi \\ Arabia \\ ${ }^{2}$ Department of Veterinary \\ Tropical Diseases, University \\ of Pretoria, South Africa \\ Correspondence to: \\ Estelle Venter \\ Email: \\ estelle.venter@up.ac.za \\ Postal address: \\ Private Bag X04, \\ Onderstepoort 0110, South \\ Africa \\ Dates: \\ Received: 20 June 2013 \\ Accepted: 21 Nov. 2013 \\ Published: 16 Oct. 2014 \\ How to cite this article: \\ Fagbo, S., Coetzer, J.A.W. \\ \& Venter, E.H., 2014 \\ 'Seroprevalence of Rift Valley \\ fever and lumpy skin disease \\ in African buffalo (Syncerus \\ caffer) in the Kruger Nationa \\ Park and Hluhluwe-iMfolozi \\ Park, South Africa', Journal of \\ the South African Veterinary \\ Association 85(1), Art. \\ \#1075, 7 pages. http:// \\ dx.doi.org/10.4102/jsava. \\ v85i1.1075 \\ Copyright: \\ C 2014. The Authors. \\ Licensee: AOSIS \\ OpenJournals. This work \\ is licensed under the \\ Creative Commons \\ Attribution License. \\ Read online:

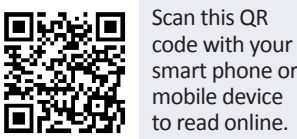

Rift Valley fever and lumpy skin disease are transboundary viral diseases endemic in Africa and some parts of the Middle East, but with increasing potential for global emergence. Wild ruminants, such as the African buffalo (Syncerus caffer), are thought to play a role in the epidemiology of these diseases. This study sought to expand the understanding of the role of buffalo in the maintenance of Rift Valley fever virus (RVFV) and lumpy skin disease virus (LSDV) by determining seroprevalence to these viruses during an inter-epidemic period. Buffaloes from the Kruger National Park $(n=138)$ and Hluhluwe-iMfolozi Park $(n=110)$ in South Africa were sampled and tested for immunoglobulin G (IgG) and neutralising antibodies against LSDV and RVFV using an indirect enzyme-linked immunosorbent assay (I-ELISA) and the serum neutralisation test (SNT). The I-ELISA for LSDV and RVFV detected IgG antibodies in 70 of 248 (28.2\%) and 15 of 248 (6.1\%) buffaloes, respectively. Using the SNT, LSDV and RVFV neutralising antibodies were found in 5 of 66 (7.6\%) and 12 of 57 (21.1\%), respectively, of samples tested. The RVFV I-ELISA and SNT results correlated well with previously reported results. Of the 12 SNT RVFV-positive sera, three (25.0\%) had very high SNT titres of 1:640. Neutralising antibody titres of more than 1:80 were found in $80.0 \%$ of the positive sera tested. The LSDV SNT results did not correlate with results obtained by the I-ELISA and neutralising antibody titres detected were low, with the highest (1:20) recorded in only two buffaloes, whilst 11 buffaloes $(4.4 \%)$ had evidence of co-infection with both viruses. Results obtained in this study complement other reports suggesting a role for buffaloes in the epidemiology of these diseases during inter-epidemic periods.

\section{Introduction}

Rift Valley fever (RVF) and lumpy skin disease (LSD) are both economically important diseases, initially endemic to sub-Saharan Africa but which have expanded into North Africa and recently the Middle East (Israel, Saudi Arabia, Yemen and Oman) (Abraham \& Zissman 1991; Fagbo 2002; Imam, Darwish \& El-Karamany 1979). Both diseases have the potential for global emergence (Britch \& Linthicum 2007; Tuppurainen \& Oura 2012).

Rift Valley fever is a mosquito-borne viral disease of domestic and wild ruminants characterised by necrotic hepatitis and haemorrhages, with often inapparent or mild infections in wild animals. The disease is caused by the Rift Valley fever virus (RVFV), a negative-sense, segmented singlestranded RNA virus of the genus Phlebovirus in the family Bunyaviridae (Rice et al. 1980). Transmission is mainly by Aedes spp. mosquitoes and transovarial transmission via aedine eggs occurs (Linthicum et al. 1985). Many other mosquito genera, such as Anopheles, Culex and Mansonia transmit RVFV (Swanepoel \& Coetzer 2004). Outbreaks of RVF in sub-Saharan Africa are usually associated with the emergence of large numbers of aedine mosquitoes following abnormally heavy rainfall with flooding. After virus amplification in vertebrates, mosquito species, such as Culex spp., act as secondary vectors to sustain the epidemic (Linthicum et al. 1985). In northern and western Africa, outbreaks have occurred independently of rainfall and transmission is mediated by river or dam breeding mosquitoes (Swanepoel \& Coetzer 2004). The isolation of RVFV from mosquitoes and detection of RVFV-specific immunoglobulin G (IgG) in animal and human populations during inter-epidemic periods are indicative of RVFV activity (LaBeaud et al. 2008; Linthicum et al. 1985; Rostal et al. 2010).

The disease was first reported in 1931 in Kenya (Daubney, Hudson \& Garnham 1931) and severe RVF outbreaks, serological evidence and/or virus isolation have since been recorded across sub-Saharan Africa (Olaleye et al. 1996; Ringot et al. 2004; Swanepoel \& Coetzer 2004; Zeller et al. 1995). The disease has expanded geographically into Egypt (Imam et al. 1979), Madagascar (Morvan et al. 1992) and Saudi Arabia and Yemen on the Arabian Peninsula (Fagbo 2002). In 
the past five years, recent outbreaks have occurred in Kenya and Madagascar (Andriamandimby et al. 2010; Bird et al. 2008). Major outbreaks in South Africa were recorded in 1950 and 1974-1975 and were preceded by wet climatic conditions that favoured an exponential rise in the vector population (Alexander 1951; Coetzer 1977). Between 2008 and 2010, RVF outbreaks occurred every year in South Africa, affecting mainly four neighbouring provinces: Mpumalanga, Limpopo, Gauteng and North-West Provinces (Paweska et al. 2010).

The role of wildlife in the epidemiology of RVF remains unclear (Evans et al. 2008; Swanepoel \& Coetzer 2004). The detection of neutralising antibodies to RVFV in African buffalo (Syncerus caffer), black rhino (Diceros bicornis), greater kudu (Tragelaphus strepsiceros), impala (Aepyceros melampus), African elephant (Loxodonta africana), kongoni (Alcelaphus buselaphus cokii) and waterbuck (Kobus ellipsiprymnus) in Kenya during an inter-epidemic period suggests that wild ruminants may serve as RVFV cycling hosts. The highest titres observed were in African buffaloes, in animals born during this period (Evans et al. 2008). Earlier experimental RVF infection of African buffalo in Kenya resulted in transient viraemia and abortion in one of the two gravid females (Davies \& Karstad 1981). Abortions have also been reported in natural RVF outbreaks in buffaloes in South Africa (Paweska, Blumberg, Weyer, Kemp, Leman, Archer et al. 2008).

Initial diagnosis of RVFV infection is based on abortions in livestock and fatalities especially in young animals. Acute febrile conditions in livestock workers may also be seen simultaneously (Swanepoel \& Coetzer 2004). Various methods are used to detect acute or past RVFV infection in animals, humans and vectors (Bird et al. 2009; Njenga et al. 2009; Swanepoel, Struthers \& Erasmus 1986). Serological tests can be used to detect RVFV-specific immunoglobulin M (IgM) or IgG in animal or human sera (Davies 1982; Paweska et al. 2003; Paweska, Burt \& Swanepoel 2005). Recently, a RVFV recombinant nucleocapsid protein (rNP) antigen indirect enzyme-linked immunosorbent assay (I-ELISA) was validated for humans, domestic ruminants and African buffaloes (Fafetine et al. 2007; Paweska, Jansen van Vuren \& Swanepoel 2007; Paweska, Jansen van Vuren, Kemp, Buss, Bengis, Gakuya et al. 2008).

Lumpy skin disease virus, a double-stranded DNA virus within the Poxviridae family is a member of the genus Capripoxvirus and closely related to goatpox and sheeppox viruses, the only other members of the genus (Buller et al. 2005). Although cattle are the definitive hosts, LSDV has been associated with an outbreak of capripox infection in Kenyan sheep (Burdin \& Prydie 1959) and LSDV-specific antibodies have been demonstrated in various wild ruminants, including blue wildebeest (Connochaetes taurinus), eland (Taurotragus oryx) giraffe (Giraffa camelopardalis), impala and greater kudu (Barnard 1997; Hedger \& Hamblin 1983). Although these two studies reported negative results in a small African buffalo population, another study detected LSDV-specific antibodies in several buffaloes from a LSDV-endemic area in Kenya (Davies 1982). African buffaloes may thus play a role in the epidemiology of LSD.

The LSDV survives for more than 30 days in skin lesions (Tuppurainen, Venter \& Coetzer 2005; Weiss 1968) and infection is characterised by fever, multiple firm circumscribed skin nodules and necrotic plaques in the mucous membranes, mastitis, orchitis and swelling of the peripheral lymph nodes (Coetzer 2004). The disease was first reported in Zambia in the late-1930s (Weiss 1968) and reached South Africa by 1944 (Thomas, Robinson \& Alexander 1945) affecting some eight million cattle (Backström 1945). It then spread throughout sub-Saharan Africa, characterised by periodic outbreaks (Davies 1991). Outside sub-Saharan Africa, LSD was first documented in Egypt (House et al. 1990), followed by Israel (Abraham \& Zissman 1991), with additional reports of serologically confirmed capripoxvirus infection in Saudi Arabia and Oman (capripoxvirus, not confirmed LSDV) (Greth et al. 1992; Kumar 2011). In South Africa, epidemics have persisted and more recent ones in 1989-1990 and 2000-2001 have been reported (Coetzer 2004). Outbreaks also occurred in 2010 in the Eastern Cape, Mpumalanga, Limpopo, Free State, Gauteng, Western Cape and North-West Provinces of South Africa (World Organisation for Animal Health 2010).

Saliva, infected skin lesions and milk have been implicated in the transmission of LSDV (Weiss 1968) and semen has experimentally been shown to transmit LSDV (Annandale et al. 2013). Direct transmission between animals is thought to be inefficient and mechanical transmission by blood-feeding arthropods has been suggested (Chihota et al. 2001). Recently, transmission of the virus by Ixodid ticks was also demonstrated (Lubinga et al. 2013; Tuppurainen et al. 2013).

Presumptive diagnosis is generally based on clinical signs, but various techniques are available for LSDV diagnosis (Awad et al. 2010; Binepal, Ongadi \& Chepkwony 2001; Tuppurainen et al. 2005). The ELISA is most suited for screening large numbers of samples for evidence of past infection. Although the serum neutralisation test (SNT) is time consuming, lacks sensitivity and cannot discriminate between antibodies to the different capripoxviruses, it is a reliable serological test (Babiuk et al. 2009).

Various ELISA protocols are available for LSDV diagnosis in cattle (Carn 1995; Heine et al. 1999; Paweska, Mortimer, Leman \& Swanepoel 2005). A recently validated ELISA that detects antibodies to LSDV in cattle using an inactivated sheeppox virus has been used. It is easier to perform, less time consuming and does not require live virus and BSL-3 facilities in LSD-free countries (Babiuk et al. 2009). However, a validated ELISA available for use in wildlife sera is lacking.

This study investigated the seroprevalence of LSDV and RVFV in stored sera of buffaloes obtained from the Kruger National Park (KNP) and Hluhluwe-iMfolozi Park (HiP), South Africa during an inter-epidemic period using an indirect ELISA (I-ELISA) and SNT. 


\section{Research method and design Sample collection}

Serum samples were collected between 2003 and 2004 from African buffaloes during a routine examination of animals in the KNP and HiP. Samples were collected from three areas in the KNP: Lower Sabie (twice sampled, once in 2003 and 2004), Gudzani Dam and Satara, as well as from the HiP in the Kwazulu-Natal Province (Figure 1). These samples (Table 1) had been stored since 2003 at $-20{ }^{\circ} \mathrm{C}$ at the Department of Veterinary Tropical Diseases, Faculty of Veterinary Science, University of Pretoria and were tested for antibodies to LSDV and RVFV.

\begin{tabular}{|c|c|c|c|}
\hline Location & $\begin{array}{l}\text { Number of } \\
\text { samples }\end{array}$ & GPS coordinates & $\begin{array}{l}\text { Month and year } \\
\text { sampled }\end{array}$ \\
\hline Lower Sabie (2003) & 51 & $25^{\circ} 12^{\prime} \mathrm{S} ; 31^{\circ} 92^{\prime} \mathrm{E}$ & July 2003 \\
\hline Lower Sabie (2004) & 41 & $25^{\circ} 12^{\prime} \mathrm{S} ; 31^{\circ} 92^{\prime} \mathrm{E}$ & September 2004 \\
\hline Gudzani Dam & 25 & $24^{\circ} 37^{\prime} \mathrm{S} ; 31^{\circ} 93^{\prime} \mathrm{E}$ & August 2003 \\
\hline Satara & 21 & $24^{\circ} 39^{\prime} \mathrm{S} ; 31^{\circ} 78^{\prime} \mathrm{E}$ & April 2003 \\
\hline Hluhluwe-iMfolozi & 110 & $28^{\circ} 28^{\prime} \mathrm{S} ; 30^{\circ} 86^{\prime} \mathrm{E}$ & September 2004 \\
\hline Total & 248 & - & - \\
\hline
\end{tabular}

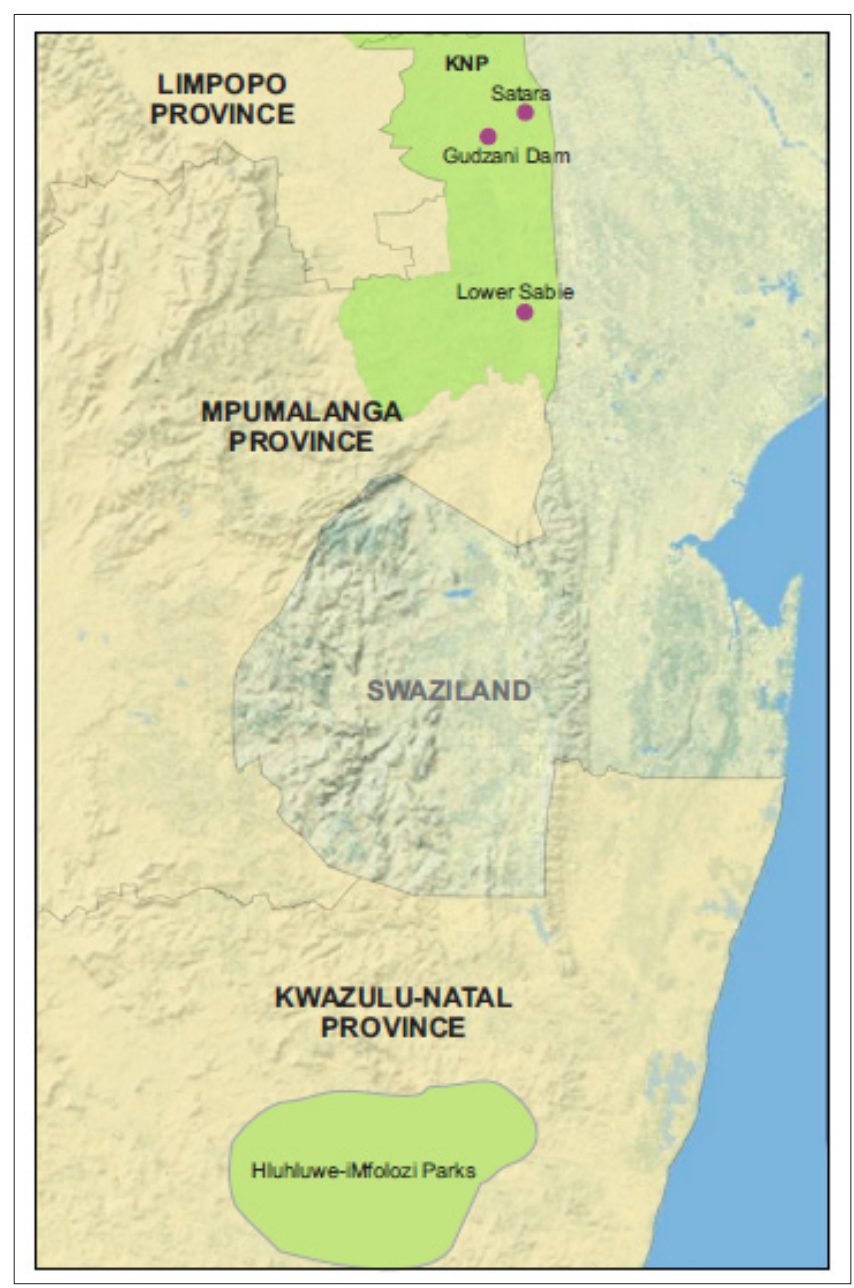

Source: Map drawn up by Estelle Mayhew

Key: Purple dots = indicate specific areas of sampling in the Kruger National Park.

FIGURE 1: Sites where samples were collected in the Kruger National Park and Hluhluwe-iMfolozi Park, South Africa.
The KNP is the largest wildlife reserve (approximately $20000 \mathrm{~km}^{2}$ ) in South Africa. It has a length and breadth of about $320 \mathrm{~km}$ and $65 \mathrm{~km}$ respectively. It is bordered by Zimbabwe in the north and Mozambique in the east. The Lower Sabie area consists of the knobthorn savanna and Lebombo bushveld ecozones, whilst the surrounding vegetation at Satara is knobtorn and marula savanna on basalt soils; no specific vegetation description of the Gudzani Dam area could be found (South African National Parks [SANParks] n.d.; Venter \& Gertenbach 1986). All three areas in the KNP experience a similar average annual rainfall of between $400 \mathrm{~mm}$ and $500 \mathrm{~mm}$, mainly during summer (December, January and February) (SA Explorer 2011; Venter \& Gertenbach 1986). As publicised on SANParks' website for the KNP (http://www.sanparks.co.za/parks/kruger/), the Park supports more than 147 mammalian species, including about 2500 African buffaloes.

The HiP is the third largest (about $900 \mathrm{~km}^{2}$ ) game reserve in South Africa. It is covered mainly by savanna grassland and the buffalo population (roughly about 3000) forms stable herds (Dora 2004).

\section{Laboratory tests}

\section{Lumpy skin disease virus IgG indirect ELISA}

The I-ELISA used was carried out as described previously with minor modifications (Babiuk et al. 2009). The cut-off value for the I-ELISA was a standard deviation (s.d.) of +3 of the mean negative control. Each buffalo serum sample was tested twice to achieve quality control. For each plate, there were three replicates of the positive and negative controls and four replicates of the conjugate controls. The internal quality control (IQC) parameters upper control limits and lower control limits were derived from the mean \pm 2 s.d. for replicates of each control (Paweska et al. 2003). Furthermore, the coefficient of variation of the positive control on each plate was monitored not to exceed $20 \%$.

\section{Rift Valley fever virus IgG indirect ELISA}

This I-ELISA protocol has been described previously and the kits were kindly provided by the Animal Research Council Onderstepoort Veterinary Institute (Jansen van Vuren et al. 2007). The mean optical density values were calculated into percentage positivity (PP) values for interpretation. Samples with PP values $>10$ were regarded as positive. Lower PP values were interpreted to mean that fewer antibodies were detected in the samples.

The IQC procedure previously described was used with minor adjustments (Paweska, Jansen van Vuren et al. 2008). Each buffalo serum was tested twice and each plate had four replicates of each high-positive serum, negative serum and conjugate controls.

\section{Serum virus neutralisation test}

Selected positive and negative ELISA sera were tested by the SNT. The SNT procedures for both viruses were 
carried out following the standard operating procedures of the Department of Veterinary Tropical Diseases, Faculty Veterinary Science, University of Pretoria (Beard et al. 2010).

\section{Lumpy skin disease virus}

The procedure was carried out using 96-well, flat-bottomed cell culture microtitre plates according to the method described by Beard et al. (2010). Bovine dermis cells were used as culturing host and a working virus concentration of $100 \mathrm{TCID}_{50}$ was used. Plates were incubated at $37^{\circ} \mathrm{C}$ in an atmosphere containing $5 \% \mathrm{CO}_{2}$ for 14 days. The end point titre was determined from the last dilution where the virus or serum mixture inhibited cytopathic effect (CPE).

\section{Rift Valley fever virus}

The same procedure for RVFV was used as with the LSDV SNT, but with minor modifications. Vero cells were used as culturing host. The plates were incubated at $37^{\circ} \mathrm{C}$ in a humid atmosphere of $5 \% \mathrm{CO}_{2}$ and observed daily for 4 days. The end point titre was determined from the last dilution where the virus or serum mixture inhibited CPE.

To ensure quality control of the SNT's of both LSDV and RVFV, virus controls were carried out in duplicate on the same plate as some, but not all, of the samples.

\section{Ethical considerations}

Samples were collected under supervision of a veterinarian during routine sampling of animals in the KNP and HiP. No animals were culled in the sampling process. All samples were transported to the BSL3 facility of the Agriculture Research Council's Transboundary Animal Diseases Section where they were inactivated. Serum samples were then brought to the Department of Veterinary Tropical Diseases at the University of Pretoria for analysis in a BSL2 laboratory.

\section{Results}

\section{Indirect ELISA}

A total of 248 serum samples were each tested using the two different I-ELISAs. LSDV antibodies were detected in $28.2 \%$ (70 of 248) of samples. The highest prevalence was recorded in the HiP where $35.5 \%$ (39 of 110) were positive. From a total of 138 samples taken in the KNP, Lower Sabie (2004) had the highest percentage of LSDV I-ELISA IgG (10 of $41 ; 24.4 \%$ ) followed by Satara with 5 positive samples ( 5 of $21 ; 23.8 \%$ ).
A total of $6.1 \%$ (15 of 248) of samples were positive using the RVF I-ELISA. The prevalence rate was highest for samples collected at Lower Sabie in 2003 (6 of 51; 11.8\%), followed by Satara ( 2 of $21 ; 9.5 \%)$. A summary of these results is shown in Table 2.

\section{Serum virus neutralisation}

A subset of samples obtained from the KNP were tested for neutralising antibodies to LSDV $(n=66)$ and RVFV $(n=57)$. These included all ELISA positive samples, samples with borderline (PP) values and selected negative samples. Some samples could not be tested by the SNT because of insufficient serum.

Of the 138 sera from the KNP tested by I-ELISA, 35 (25.4\%) were tested for neutralising antibodies to LSDV and 38 $(27.5 \%)$ to RVFV by the SNT. Only five sera were positive for these antibodies to LSDV, three taken from Lower Sabie in 2003 and two from Gudzani Dam; nine sera were positive for antibodies to RVFV, the majority (88.9\%; 8 of 9) of which were from Lower Sabie. None of the sera from Satara tested positive for $\operatorname{LSDV}(n=7)$ or $\operatorname{RVFV}(n=4)$ neutralising antibodies (Table 3). Of the samples from HiP that were tested for both viruses using the I-ELISA, 31 of 110 (28.2\%) were tested for LSDV and 19 of 110 (17.3\%) for RVFV using the SNT. None of these had neutralising antibodies to LSDV and three were positive for antibodies to RVFV (Table 3).

\section{Discussion}

Evidence of natural and experimental infections with RVFV and LSDV in wildlife has been documented (Davies \& Karstad 1981; Evans et al. 2008; Hedger \& Hamblin 1983; Young, Basson \& Weiss 1970). In this study, sera were collected from buffaloes during an inter-epidemic period in the KNP and HiP regions and the prevalence of antibodies to both LSDV and RVFV was obtained using I-ELISA protocols. Selected positive and negative sera from the ELISA were then tested using the SNT.

Based on RVFV IgG detection, a prevalence of $6.5 \%$ (9 of 138 ) and $4.5 \%$ (5 of 110 ) in the KNP and HiP, respectively, were obtained in this study. Other studies similar to this one include those of Anderson and Rowe (1998), Barnard (1997), LaBeaud et al. (2011) and Wolhuter et al. (2009). In the earliest study, all 71 buffaloes (from the KNP) tested were negative. Another study from the KNP reported a seroprevalence of $57.6 \%$ (117 of 203), although the ELISA used was not described (Wolhuter et al. 2009). The most recent study

TABLE 2: Indirect ELISA results for lumpy skin disease virus and Rift Valley fever virus.

\begin{tabular}{|c|c|c|c|c|c|}
\hline \multirow[t]{2}{*}{ Location } & \multirow{2}{*}{$\begin{array}{l}\text { Total number of } \\
\text { samples }\end{array}$} & \multicolumn{2}{|c|}{ LSDV } & \multicolumn{2}{|c|}{ RVFV } \\
\hline & & Positive samples & Positive samples in \% & Positive samples & Positive samples in \% \\
\hline Lower Sabie (2003) & 51 & 13 & 25.5 & 6 & 11.8 \\
\hline Lower Sabie (2004) & 41 & 10 & 24.4 & 1 & 2.4 \\
\hline Gudzani Dam & 25 & 3 & 12.0 & 1 & 4.0 \\
\hline Satara & 21 & 5 & 23.8 & 2 & 9.5 \\
\hline Hluhluwe-iMfolozi Park & 110 & 39 & 35.5 & 5 & 4.5 \\
\hline Total & 248 & 70 & 28.2 & 15 & 6.1 \\
\hline
\end{tabular}

LSDV, lumpy skin disease virus; RVFV, Rift Valley fever virus. 
TABLE 3: Serum virus neutralisation test results for lumpy skin disease virus and Rift Valley fever virus.

\begin{tabular}{|c|c|c|c|c|c|c|}
\hline \multirow[t]{2}{*}{ Location } & \multicolumn{3}{|c|}{ LSDV } & \multicolumn{3}{|c|}{ RVFV } \\
\hline & $\begin{array}{c}\text { Total number of } \\
\text { samples } \dagger\end{array}$ & $\begin{array}{l}\text { Positive } \\
\text { samples }\end{array}$ & $\begin{array}{c}\text { Positive } \\
\text { samples in \% }\end{array}$ & $\begin{array}{c}\text { Total number of } \\
\text { samples }\end{array}$ & $\begin{array}{l}\text { Positive } \\
\text { samples }\end{array}$ & $\begin{array}{c}\text { Positive } \\
\text { samples in \% }\end{array}$ \\
\hline Lower Sabie (2003) & 14 & 3 & 21.4 & 16 & 7 & 53.9 \\
\hline Lower Sabie (2004) & 10 & 0 & 0.0 & 11 & 1 & 9.1 \\
\hline Gudzani Dam & 4 & 2 & 50.0 & 7 & 1 & 14.3 \\
\hline Satara & 7 & 0 & 0.0 & 4 & 0 & 0.0 \\
\hline Hluhluwe-iMfolozi Park & 31 & 0 & 0.0 & 19 & 3 & 15.8 \\
\hline Total & 66 & 5 & 7.6 & 57 & 12 & 21.1 \\
\hline
\end{tabular}

LSDV, lumpy skin disease virus; RVFV, Rift Valley fever virus; ELISA, enzyme-linked immunosorbent assay.

$\dagger$, Nine samples not tested due to insufficient sera - all were ELISA positive.

\#. Three samples not tested due to insufficient sera - one ELISA positive and two ELISA negatives.

reported $21.0 \%$ prevalence in 550 buffaloes tested from the KNP using only the haemagglutination inhibition (HAI) (LaBeaud et al. 2011). In the study performed in Zimbabwe, where both the IgG ELISA and a HAI protocol were used, 34 of 514 (6.3\%) buffaloes were positive (Anderson \& Rowe 1998). Other studies using buffalo sera either did not specify when samples were taken (epidemic or inter-epidemic period) or samples were from both periods (Evans et al. 2008; Paweska et al. 2007; Paweska, Jansen van Vuren, Kemp et al. 2008; Paweska, Mortimer, Leman \& Swanepoel 2005).

In the present study, $21.1 \%$ (12 of 57) of samples tested RVFVpositive by the SNT. Results obtained by previous studies, where larger sample sizes were used, reported by Paweska et al. (2003) (5.8\%; 54 of 928); Paweska, Jansen van Vuren, Kemp, Buss, Bengis, Gakuya et al. (2008) (7.5\%; 77 of 1023) and Evans et al. (2008) (15.6\%; 37 of 237), were lower than those obtained in this study. Results obtained by the study of Paweska, Mortimer, Leman and Swanepoel (2005) (20.5\%; 53 of 258) are similar to those of the present study. However, that study included samples obtained from an outbreak during 1997-1998 in East Africa, the proportion of which was not stated in the paper.

A high correlation between results obtained by the I-ELISA and the SNT (Pearson's correlation coefficient) was evident in the studies of Evans et al. (2008) $\left(R^{2}=0.860\right)$ and Paweska, Jansen van Vuren, Kemp et al. (2008) $\left(R^{2}=0.882\right.$ Spearman test). A comparable high correlation was also obtained in this study between the SNT titres and the PP values from the I-ELISA. The Pearson's correlation coefficient was $R^{2}=0.750$. This study provides additional evidence that the rNP-based I-ELISA is a valuable diagnostic tool for RVFV seroprevalence studies in the African buffalo.

From a total of 248 buffalo sera tested, 70 (28.2\%) were positive for antibodies to LSDV (ELISA). In previous similar LSDV prevalence studies, African buffalo sera were collected between 1963 and 1996 (Barnard 1997; Davies 1982; Hamblin et al. 1990; Hedger \& Hamblin 1983) and the SNT was mainly used to detect neutralising antibodies to LSDV (Barnard 1997); another combined the SNT with the indirect fluorescent antibody test (IFAT) (Davies 1982). In the present study, the LSDV SNT detected neutralising antibodies in 5 of $66(7.6 \%)$ samples, some of them with low titres of, for example, 1:20. In the study by Barnard (1997), 15 buffalo samples from the KNP were tested and although antibodies to LSDV were detected in wildebeest, eland, springbok and impala, no antibodies to LSDV could be detected in buffaloes. The small number of buffaloes tested was probably not representative of the potentially infected buffaloes in the KNP. Davies (1982) detected neutralising antibodies in buffalo sera collected during epidemic and inter-epidemic periods in Kenya, Tanzania and Uganda. He indicated that a subset of the IFAT positive samples (150 of $254 ; 59.1 \%$ ) were positive by SNT without giving the exact number. Another study, with a much larger and more diverse sample size than the present study, tested more wild ruminant species $(n=8)$ from different game areas in Tanzania (Hamblin et al. 1990). Although all the 370 buffalo sera tested were negative for LSDV neutralising antibodies, information on disease activity at the time of sampling was lacking (Hamblin et al. 1990). The largest LSDV prevalence study in buffalo tested samples collected between 1963 and 1982 from 11 sub-Saharan African countries and all the samples (1413) were negative for LSDV neutralising antibodies (Hedger \& Hamblin 1983).

The SNT is not very sensitive in detecting LSDV neutralising antibodies because of the predominantly cell-mediated immune response to LSDV infection (Babiuk et al. 2009). Additionally, LSDV does not easily grow in cell cultures, which makes the SNT difficult to perform. However, the use of bovine dermis cells, a primary cell culture, in this study may have contributed to the sensitivity of the SNT. These cells have previously been used to detect LSDV in blood and semen of experimentally infected bulls (Bagla et al. 2006; Tuppurainen et al. 2005).

Earlier researchers using a cloned capripoxvirus structural protein (P32) antigen showed that the ELISA was more sensitive than the SNT in detecting LSDV antibodies in bovine sera (Carn et al. 1994). The current study on buffalo sera had a fairly large sample size and the I-ELISA detected a high percentage $(28.2 \%)$ of positive samples. However, the results obtained by the SNT, although it is the gold standard, did not compare well with results obtained by the I-ELISA used in this study. A purified, heat-inactivated, Nigerian sheeppox virus as coating antigen was used (Babiuk et al. 2009) in this I-ELISA and was not specifically validated for wildlife sera.

Difficulties encountered with development and evaluation of serodiagnostic tests for capripoxviruses have been in obtaining sufficiently large numbers of well-characterised 
sera from different host species (e.g. sheep, goats, cattle and buffalo) to facilitate validation (Timothy Bowden pers. comm., 03 June 2011). There are also a large number of host (including breed, age, sex, previous infection or vaccination history, quality of sera etc.) and laboratory sheeppox virus factors that might affect the performance characteristics (diagnostic sensitivity and diagnostic specificity) of any antibody-detecting ELISA. Determining the true exposure status of naturally infected animals is therefore often difficult. It is therefore not unusual to obtain a large percentage of seropositive animals, as in this study, using the ELISA.

The high percentage of LSDV-positive antibody results obtained in this study is, however, a concern. Results are in contrast with other published results, as well as results obtained with the SNT for antibodies against LSDV. Samples were obtained from the field and the possibility that the results by the I-ELISA are false positives cannot be excluded. A validated LSDV-specific ELISA, although difficult to establish, should be used for testing buffalo and other wildlife sera.

\section{Conclusion}

This study provides data indicating previous infection by LSDV and RVFV in an African buffalo population in the KNP and HiP during an inter-epidemic period. The role of buffaloes in the epidemiology of these diseases is, however, still not clear. From the results obtained, both the SNT and ELISA tests used for RVFV are sensitive and provide reproducible results. However, further studies are required to evaluate the performance characteristics (sensitivity and especially the specificity) of the I-ELISA assay for the detection of antibodies against LSDV in African buffalo serum in order to detect the true prevalence of LSDV antibodies in buffalo. In particular, a large number of known LSD-negative serum samples should be tested using the I-ELISA.

\section{Acknowledgements Competing interests}

The authors declare that they have no financial or personal relationships which may have inappropriately influenced them in writing this article.

\section{Authors' contributions}

E.H.V. (University of Pretoria) was the project leader and responsible for the project design and writing of the manuscript. J.A.W.C. (University of Pretoria) assisted in the project design and writing of the manuscript. S.F. (Ministry of Health) did the experimental work and assisted in writing the manuscript.

\section{References}

Abraham, A. \& Zissman, A., 1991, 'Isolation of lumpy skin disease virus in Israel', Israeli Journal of Veterinary Medicine 46, 20-23.

Alexander, R.A., 1951, 'Rift Valley fever in the Union', Journal of the South African Veterinary Association 22, 105-109.
Anderson, E.C. \& Rowe, L.W., 1998, 'The prevalence of antibody to the viruses of bovine virus diarrhoea, bovine herpes virus 1, rift valley fever, ephemeral fever and bluetongue and to Leptospira sp. in free-ranging wildlife in Zimbabwe', Epidemiology and Infection 121, 441-449. http://dx.doi.10.1017/ S0950268898001289

Andriamandimby, S.F., Randrianarivo-Solofoniania, A.E., Jeanmaire, E.M., Ravolomanana, L., Razafimanantsoa L.T., Rakotojoelinandrasana, T. et al., 2010 'Rift Valley fever during rain seasons, Madagascar, 2008 and 2009', Emerging Infectious Diseases 16(6), 963-970. http://dx.doi.10.3201/eid1606.091266

Annandale, C.H., Holm, D.E., Ebersohn, K. \& Venter, E.H., 2013, 'Seminal transmission of lumpy skin disease virus in heifers', Transboundary and Emerging Diseases. http://dx.doi.org/10.1111/tbed.12045

Awad, W.S., Ibrahim, A.K., Mahran, K., Fararh, K.M. \& Abdel Moniem, M.I., 2010, 'Evaluation of different diagnostic methods for diagnosis of lumpy skin disease in cows', Tropical Animal and Health Production 42, 777-783. http://dx.doi.10.1007/ s11250-009-9486-5

Babiuk, S., Wallace, D.B., Smith, S.J., Bowden, T.R., Dalman, B., Parkyn, G. et al., 2009, 'Detection of antibodies against capripoxviruses using an inactivated sheep pox virus ELISA', Transboundary and Emerging Diseases 56(4), 132-141. http:// dx.doi.10.1111/j.1865-1682.2009.01067.x

Backström, U., 1945, 'Ngamiland cattle disease: Preliminary report on a new disease, the aetiological agent being probably of an infectious nature', Journal of the South African Veterinary Medical Association 16, 29-35.

Bagla, V.P., Osuagwuh, U.I., Annandale, C.H., Irons, P.C. \& Venter, E.H., 2006, 'Elimination of toxicity and enhanced detection of lumpy skin disease virus on cell culture from experimentally infected bovine semen samples', Onderstepoort cell culture from experimentally infected bo
Journal of Veterinary Research 73, 263-268.

Barnard, B.J., 1997, 'Antibodies against some viruses of domestic animals in southern African wild animals', Onderstepoort Journal of Veterinary Research 64, 95-110.

Beard, P.M., Sugar, S., Bazarragchaa, E., Gerelmaa, U., Tserendorj, S., Tuppurainen, E. et al., 2010, 'A description of two outbreaks of Capripoxvirus disease in Mongolia', Veterinary Microbiology 142, 427-431. http://dx.doi.10.1016/j. vetmic.2009.10.018

Binepal, Y.S., Ongadi, F.A. \& Chepkwony, J.C., 2001, 'Alternative cell lines for the propagation of lumpy skin disease virus', Onderstepoort Journal of Veterinary Research 68, 151-153.

Bird, B.H., Githinji, J.W., Macharia, J.M., Kasiiti, J.L., Muriithi, R.M., Gacheru, S.G. et al., 2008, 'Multiple virus lineages sharing recent common ancestry were associated with a large Rift Valley fever outbreak among livestock in Kenya during 20062007', Journal of Virology 82(22), 11152-11166. http://dx.doi.10.1128/JVI.015192007

Bird, B.H., Ksiazek, T.G., Nichol, S.T. \& Maclachlan, N.J., 2009, 'Rift Valley fever virus', Journal of the American Veterinary Medical Association 234, 883-893. http:// dx.doi.org/10.2460/javma.234.7.883

Britch, S.C. \& Linthicum, K.J., 2007, 'Rift Valley Fever working group. Developing a research agenda and a comprehensive national prevention and response plan for Rift Valley fever in the United States', Emerging Infectious Diseases 13(8), viewed 31 March 2010, from http://www.cdc.gov/EID/content/13/8/e1.htm

Buller, R.M., Arif, B.M., Black, D.N., Dumbell, K.R., Esposito, J.J., Lefkowitz, E.J. et al., 2005, 'Family Poxviridae', in C.M. Fauquet, M.A. Mayo, J. Maniloff, U. Desselberger $\&$ L.A. Ball (eds.), Virus taxonomy: Classification and nomenclature of viruses. Eighth report of the International Committee on Taxonomy of Viruses, pp. 117133, Elsevier Academic Press, San Diego.

Burdin, M.L. \& Prydie, J., 1959, 'Observations on the first outbreak of lumpy skin disease in Kenya', Bulletin of Epizootic Diseases of Africa 7, 21-26.

Carn, V.M., 1995, 'An antigen trapping ELISA for the detection of capripoxvirus in tissue culture supernatant and biopsy samples', Journal of Virological Methods 51, 95-102. http://dx.doi.10.1016/0166-0934(94)00138-7

Carn, V.M., Kitching, R.P., Hammond, J.M. \& Chand, P., 1994, 'Use of a recombinant antigen in an indirect ELISA for detecting bovine antibody to capripoxvirus', Journal of Virological Methods 49, 285-294. http://dx.doi.10.1016/01660934(95)00027-R

Chihota, C.M., Rennie, L.F., Kitching, R.P. \& Mellor, P.S., 2001, 'Mechanical transmission of lumpy skin disease virus by Aedes aegypti (Diptera: Culicidae)', Epidemiology and Infection 126, 317-321. http://dx.doi.org/10.1017/S0950268801005179

Coetzer, J.A.W., 1977, 'The pathology of Rift Valley fever. I. Lesions occurring in natural cases in newborn lambs', Onderstepoort Journal of Veterinary Research 44, 205212.

Coetzer, J.A.W., 2004, 'Lumpy skin disease', in J.A.W. Coetzer \& R.C. Tustin (eds.), Infectious diseases of livestock, vol. 2, 2nd edn., pp. 1268-1276, Oxford University Press, Cape Town.

Daubney, R., Hudson, J.R. \& Garnham, P.C., 1931, 'Enzootic hepatitis or Rift Valley fever: An undescribed virus disease of sheep, cattle and man from East Africa' fever: An undescribed virus disease of sheep, cattle and man from East Africa', path.1700340418

Davies, F.G., 1982, 'Observations on the epidemiology of lumpy skin disease in Kenya', Journal of Hygiene, London 88, 95-102. http://dx.doi.org/10.1017/ S002217240006993X

Davies, F.G., 1991, 'Lumpy skin disease, an African Capripox virus disease of cattle', British Veterinary Journal 147, 489-503. http://dx.doi.org/10.1016/00071935(91)90019-J

Davies, F.G. \& Karstad, L., 1981, 'Experimental infection of the African buffalo with the virus of Rift Valley fever', Tropical Animal Health and Production 13, 185-188. http://dx.doi.10.1007/BF02237921

Dora, C.A., 2004, 'The influences of habitat structure and landscape heterogeneity on African buffalo (Syncerus caffer) group size in Hluhluwe-iMfolozi Park, South Africa', MSc thesis in Environmental Science, Oregon State University. 
Evans, A., Gakuya, F., Paweska, J.T., Rostal, M., Akoolo, L., Jansen van Vuren, P.J. et al., 2008, 'Prevalence of antibodies against Rift Valley fever virus in Kenyan wildlife', Epidemiology and Infection 136(9), 1261-1269. http://dx.doi.10.1017/ wildlife', Epidemiology

Fafetine, J.M., Tijhaar, E., Paweska, J.T., Neves, L.C., Hendriks, J., Swanepoel, R. et al., 2007, 'Cloning and expression of Rift Valley fever virus nucleocapsid (N) protein and evaluation of a N-protein based indirect ELISA for the detection of specific IgG and IgM antibodies in domestic ruminants', Veterinary Microbiology 121(1-2), IgG and IgM antibodies in domestic ruminants', Vete

Fagbo, S.F., 2002, 'The evolving transmission pattern of Rift Valley fever in the Arabian Peninsula', Annals of the New York Academy of Science 969, 201-204. http:// dx.doi.org/10.1111/j.1749-6632.2002.tb04378.x

Greth, A., Gourreau, J.M., Vassart, M., Nguyen-Ba-Vy, Wyyers, M. \& Lefevre P.C., 1992 'Capripoxvirus disease in an Arabian Oryx (Oryx leucoryx) from Saudi Arabia', Journal of Wildlife Diseases 28, 295-300. http://dx.doi.org/10.7589/0090-355828.2.295

Hamblin, C., Anderson, E.C., Jago, M., Mlengeya, T. \& Hipji, K., 1990, 'Antibodies to some pathogenic agents in free-living wild species in Tanzania', Epidemiology and Infection 105, 585-594. http://dx.doi.org/10.1017/S0950268800048226

Hedger, R.S. \& Hamblin, C., 1983, 'Neutralising antibodies to lumpy skin disease virus in African wildlife', Comparative Immunology, Microbiology and Infectious Diseases 6, 209-213. http://dx.doi.10.1016/0147-9571(83)90012-7

Heine, H.G., Stevens, M.P., Foord, A.J. \& Boyle, D.B., 1999, 'A capripoxvirus detection PCR and antibody ELISA based on the major antigen P32, the homolog of the vaccinia virus H3L gene', Journal of Immunological Methods 227, 187-196. http:// dx.doi.10.1016/S0022-1759(99)00072-1

House, J.A., Wilson, T.M., El Nakashly, S., Karim, I.A., Ismail, I., El Danaf, N. et al., 1990 'The isolation of lumpy skin disease virus and bovine herpesvirus- from cattle in Egypt', Journal of Veterinary Diagnostic Investigation 2, 111-115. http://dx.doi. org/10.1177/104063879000200205

Imam, I.Z., Darwish, M.A. \& El-Karamany, R., 1979, 'Epidemic of Rift Valley fever in Egypt. I. Diagnosis of Rift Valley fever in man', Bulletin of the World Health in Egypt. I. Diagnosis of Rift
Organization 57, 437-439.

Jansen van Vuren, P.J., Potgieter, A.C., Paweska, J.T. \& Van Dijk, A.A., 2007, 'Preparation and evaluation of a recombinant Rift Valley fever virus $\mathrm{N}$ protein for the detection of IgG and IgM antibodies in humans and animals by indirect ELISA', Journal of of IgG and IgM antibodies in humans and animals by indirect ELISA', Journal of
Virological Methods 140, 106-114. http://dx.doi.10.1016/j.jviromet.2006.11.005

Kumar, S.M., 2011, 'An outbreak of lumpy skin disease in a Holstein dairy herd in Oman: A clinical report', Asian Journal of Animal and Veterinary Advances 6, 851859. http://dx.doi.10.3923/ajava.2011.851.859

LaBeaud, A.D., Muchiri, E.M., Ndzovu, M., Mwanje, M.T., Muiruri, S., Peters, C.J. et al., 2008, 'Interepidemic Rift Valley fever virus seropositivity, northeastern Kenya', Emerging Infectious Diseases 14(8), 1240-1246. http://dx.doi.10.3201/ eid1408.080082

LaBeaud, A.D., Cross, P.C., Getz, W.M., Glinka, A. \& King, C.H., 2011, 'Rift Valley fever virus infection in African buffalo (Syncerus caffer) herds in rural South Africa: Evidence of interepidemic transmission', American Journal of Tropical Medicine and Hygiene 84, 641-646. http://dx.doi.10.4269/ajtmh.2011.10-0187

Linthicum, K.J., Davies, F.G., Kairo, A. \& Bailey, C.L., 1985, 'Rift Valley fever virus (family Bunyaviridae, genus Phlebovirus). Isolations from diptera collected during an inter-epizootic period in Kenya', Journal of Hygiene, London 95, 197-209. http:// dx.doi.org/10.1017/S0022172400062434

Lubinga, J., Tuppurainen, E., Ebersohn, K., Coetzer, J.A.W., Stoltsz, H. \& Venter, E.H., 2013, 'Detection of lumpy skin disease virus in saliva of ticks fed on lumpy skin disease virus infected cattle', Experimental and Applied Acarology 61, 129-138. $\mathrm{http} / / / \mathrm{dx}$.doi.10.1007/s10493-013-9679-5

Morvan, J., Rollin, P.E., Laventure, S., Rakotoarivony, I. \& Roux, J., 1992, 'Rift Valley fever epizootic in the central highlands of Madagascar', Research in Virology 143 407-415. http://dx.doi.10.1016/S0923-2516(06)80134-2

Njenga, M.K., Paweska, J., Wanjala, R., Rao, C.Y., Weiner, M., Ombaila, V. et al., 2009, 'Using a field quantitative real-time PCR test to rapidly identify highly viraemic Rift Valley fever cases', Journal of Clinical Microbiology 47, 1166-1171. http:// Rift Valley fever cases', Journal
dx.doi.10.1128/JCM.01905-08

Olaleye, O.D., Tomori, O., Ladipo, M.A. \& Schmitz, H., 1996, 'Rift Valley fever in Nigeria: Infections in humans', Revue Scientifique et Technique OIE 15, 923-935.

Paweska, J.T., Burt, F.J. \& Swanepoel, R., 2005, 'Validation of IgG-sandwich and IgMcapture ELISA for the detection of antibody to Rift Valley fever virus in humans', Journal of Virological Methods 124, 173-181. http://dx.doi.org/10.1016/j. jviromet.2004.11.020

Paweska, J.T., Jansen van Vuren, P.J. \& Swanepoel, R., 2007, 'Validation of an indirect ELISA based on a recombinant nucleocapsid protein of Rift Valley fever virus for the detection of IgG antibody in humans', Journal of Virological Methods 146, 119-124. http://dx.doi.10.1016/j.jviromet.2007.06.006
Paweska, J.T., Mortimer, E., Leman, P.A. \& Swanepoel, R., 2005, 'An inhibition enzymelinked immunosorbent assay for the detection of antibody to Rift Valley fever virus in humans, domestic and wild ruminants', Journal of Virological Methods, virus in humans, domestic and wild ruminants', Journal
127 10-18. http://dx.doi.10.1016/j.jviromet.2005.02.008

Paweska, J.T, Blumberg, L., Weyer, J., Kemp, A., Leman P., Archer, B. et al., 2008, 'Rift Valley fever outbreak in South Africa', Communicable Diseases Surveillance Bulletin 6, 1-2.

Paweska, J.T., Jansen van Vuren, P.J., Kemp, A., Buss, P., Bengis, R.G., Gakuya, F. et al., 2008, 'Recombinant nucleocapsid-based ELISA for detection of IgG antibody to Rift Valley fever virus in African buffalo', Veterinary Microbiology 127(1-2), 21-28. http://dx.doi.10.1016/j.vetmic.2007.07.031

Paweska, J.T., Smith, S.J., Wright, I.M., Williams, R., Cohen, A.S., Van Dijk, A.A. et al., 2003, 'Indirect enzyme-linked immunosorbent assay for the detection of antibody against Rift Valley fever virus in domestic and wild ruminant sera', Onderstepoort Journal of Veterinary Research 70, 49-64.

Paweska, J.T., Weyer, J., Jansen van Vuren, P., Kemp, A., Roux C., Leman, P. et al., 2010 'Update on the 2010 Rift Valley fever outbreak in South Africa', Arbo-Zoonet News 5, 7-13.

Rice, R.J., Erlick, B.J., Rosato, R.R., Eddy, G.E. \& Mohanty, S.B., 1980, 'Biochemical characterization of Rift Valley fever virus', Virology 105, 256-260. http://dx.d oi.10.1016/0042-6822(80)90175-0

Ringot, D., Durand, J.P., Tolou, H., Boutin, J.P. \& Davoust, B., 2004, 'Rift Valley fever in Chad', Emerging Infectious Diseases 10, 945-947. http://dx.doi.org/10.3201/ eid1005.030621

Rostal, M., Evans, A., Sang, R., Gikundi, S., Wakhule, L., Munyua, P. et al., 2010 'Identification of potential vectors of and detection of antibodies against Rift Valley fever virus in livestock during interepizootic periods', American Journal of Veterinary Research 71, 522-526. http://dx.doi.org/10.2460/ajvr.71.5.522

SA Explorer, 2011, Satara rest camp (Kruger) climate, viewed 17 April 2014, from http://www.saexplorer.co.za/south-africa/climate/satara_rest_camp_(kruger) climate.asp

South African National Parks, n.d., Satara rest camp, viewed 17 April 2014, from http://www.sanparks.org/parks/kruger/camps/satara/conservation/ff/default. php

Swanepoel, R. \& Coetzer, J.A.W., 2004, 'Rift Valley fever', in J.A.W. Coetzer \& R.C. Tustin (eds.), Infectious diseases of livestock, vol. 2, 2nd edn., pp. 1037-1070, Oxford (eds.), Infectious diseases of
University Press, Cape Town.

Swanepoel, R., Struthers, J.K. \& Erasmus, M.J., 1986, 'Comparison of techniques for demonstrating antibodies to Rift Valley fever virus', Journal of Hygiene, London 97, 317-329. http://dx.doi.org/10.1017/S0022172400065414

Thomas, A.D., Robinson, E.M. \& Alexander, R.A., 1945, 'Lumpy skin disease knopvelsiekte', Onderstepoort Division of Veterinary Services, Veterinary Newsletter 10

Tuppurainen, E.S.M., Lubinga, J.C., Stoltsz, W.H., Troskie, M., Carpenter, S.T., Coetzer, J.A.W. et al., 2013, 'Mechanical transmission of lumpy skin disease virus by Rhipicephalus appendiculatus male ticks', Epidemiology and Infection 141(2), 425-430. http://dx.doi.org/10.1017/S0950268812000805

Tuppurainen, E.S. \& Oura, C.A., 2012, 'Review: Lumpy skin disease: An emerging threat to Europe, the Middle East and Asia', Transboundary and Emerging Diseases 59 , 40-48. http://dx.doi.10.1111/j.1865-1682.2011.01242.x

Tuppurainen, E.S., Venter, E.H. \& Coetzer, J.A.W., 2005, 'The detection of lumpy skin disease virus in samples of experimentally infected cattle using different diagnostic techniques', Onderstepoort Journal of Veterinary Research 72, 153diagnostic techniques', Onderstepoort Journal
164. http://dx.doi.org/10.4102/ojvr.v72i2.213

Venter, F.J. \& Gertenbach, W.P., 1986, 'A cursory review of the climate and vegetation of the Kruger National Park', Koedoe 29, 139-148. http://dx.doi.org/10.4102/ koedoe.v29i1.526

Weiss, K.E., 1968, 'Lumpy skin disease virus', Virology Monographs 3, 111-131. http:// dx.doi.org/10.1007/978-3-662-39771-8_3

Wolhuter, J., Bengis, R.G., Reilly, B.K. \& Cross, P.C., 2009, 'Clinical demodicosis in African buffalo (Syncerus caffer) in the Kruger National Park', Journal of Wildlife Diseases 45, 502-504. http://dx.doi.org/10.7589/0090-3558-45.2.502

World Organisation for Animal Health, 2010, Lumpy skin disease - South Africa viewed 12 December 2010, from http://www.oie.int/wahis_2/public/wahid.php/ viewed 12 December 2010, from

Young, E., Basson, P.A. \& Weiss, K.E., 1970, 'Experimental infection of game animals with lumpy skin disease virus (prototype strain, Neethling)', Onderstepoort Journal of Veterinary Research 37, 79-88.

Zeller, H.G., Bessin, R., Thiongane, Y., Bapetel, I., Teou, K., Gbaguidi Ala, M. et al., 1995, 'Rift valley fever antibody prevalence in domestic ungulates in Cameroon and several West African countries (1989-1992) following the 1987 Mauritanian outbreak', Research in Virology 146, 81-85. http://dx.d oi.10.1016/0923-2516(96)80593-0 